Acta Veterinaria (Beograd), Vol. 63, No. 5-6, 655-663, 2013.

DOI: 10.2298/AVB1306655K

UDK: $579.842 .14+637.5^{\prime} 64+637.514 .5: 637 \cdot 5 \cdot 037$

\title{
BEHAVIOR OF SALMONELLA TYPHIMURIUM IN PORK MINCED MEAT AND PORK SKIN AT DIFFERENT STORAGE TEMPERATURES
}

\author{
KARABASIL N*, TEODOROVIĆ $V^{*}$, DIMITRIJEVIĆ MIRJANA*, PAVLIĆEVIĆ NATAŠA**, \\ KURELJUŠIĆ JASNA ${ }^{* * *}$, ĐURIĆ SPOMENKA*, SOČO IVAN*** \\ and SAVIĆ RADOVANOVIĆ RADOSLAVA* \\ *University of Belgrade, Faculty of Veterinary Medicine, Belgrade, Serbia \\ ** Veterinary Specialistic Institute "Subotica", Subotica, Serbia \\ ${ }^{* * *}$ Scientific Veterinary Institute of Serbia, Belgrade
}

(Received $3^{\text {rd }}$ June 2013)

Salmonella is a common contaminant of pork and can present a health hazard to consumers. Therefore, for an effective control, the entire supply chain must be involved. The aim of this paper is to examine the survival of Salmonella Typhimurium in pork minced meat and skin at different temperatures and time. In minced meat, stored at $+4 \pm$ $0.5^{\circ} \mathrm{C}$ during $72 h$, the number of Salmonella Typhimurium of all three examined strains $A, B$, and $C$ decreased $(p<0.01)$. In minced meat, stored at $+10 \pm 1^{\circ} \mathrm{C}$ after $72 \mathrm{~h}$, the number of Salmonella strain $A$ was significantly higher $(p<0.01)$, while for strains $B$ and $C$, no statistically significant difference was determined $(p>0.05)$. On the skin, stored at $+4 \pm 0.5^{\circ} \mathrm{C}$ during $72 \mathrm{~h}$, the number of Salmonella of strains $A$ and $B$ decreased $(p<0.01)$, while for strain $C$, no statistically significant difference was determined ( $p>0.05)$. On the skin, stored at $+10 \pm 1^{\circ} \mathrm{C}$ during $72 \mathrm{~h}$, the number of Salmonella of strains $A$ and $C$ decreased $(p<0.01)$, while for strain $B$, no statistically significant difference was determined $(p>0.05)$.

Key words: minced meat, pork, Salmonella, skin, temperature

\section{INTRODUCTION}

Salmonella can enter the food production process, e.g. in the primary stages by feed, people and rodents, during transport in contaminated lorries or at the slaughterhouses by cross contamination of animals and etc (Prendergast et al., 2009; Karabasil et al., 2008; Small et al., 2002). This pathogen is a common contaminant of pork and can present a health hazard to consumers. Therefore, for an effective control, the entire supply chain must be involved. In Serbia, Salmonella Enteritidis is considered the most important foodborne Salmonella 
causing illness in humans, followed by Salmonella Typhimurium (Institute of Public Health of Serbia and WHO, 2010). Pigs are an important reservoir of Salmonella Typhimurium (Delhalle et al., 2009) and is the most frequent serotype isolated from porcine meat (Jordan et al., 2006). The percentage and prevalence of Salmonella serotypes isolated from different surfaces in lairage, stunning boxes and from pork carcasses were as follows (Karabasil et al., 2012c): Salmonella Typhimurium 68.6\% (48/70), Salmonella Mbandaka 17.1\% (12/70), Salmonella Senftenberg $8.6 \%$ (6/70), Salmonella Bredeney 4.3\% (3/70) and Salmonella Menston 1.4\% (1/70). Surfaces in pig lairages and in stunning boxes are regularly contaminated with Salmonella (Karabasil et al., 2012a). Salmonella was isolated from 46.7\% of examined carcasses immediately after stunning (Karabasil et al., 2012b). The contamination rates for the different carcass areas were: brisket $30.0 \%$, flank $23.3 \%$ and rump $13.3 \%$. When contaminated carcasses are being processed, the main risk factors regarding cross contamination are inapt cleaning and disinfection, and manipulation of contaminated material (Janković et al., 2012). Risk factors for human Salmonella infection include the consumption of contaminated meats, and handling of contaminated raw meat and cross-contamination with ready-to-eat products (Smerdon et al., 2001). The aim of this paper is to examine the survival of Salmonella Typhimurium in pork minced meat and skin at different refrigeration temperatures and times.

\section{MATERIAL AND METHODS}

Microorganisms: Salmonella Typhimurium collections were made of two strains from slaughterhouse source: strain A and B (Faculty of Veterinary Medicine Belgrade); and one strain from clinical/human source: strain C (Public Health Institute of Serbia).

Samples for "in vitro" examination: Minced meat was prepared from pork ham (diameter grinders $6 \mathrm{~mm}$ ) negative on Salmonella. $\mathrm{pH}$ of minced meat was 5.89. Prepared samples (50 g per sample) were contaminated with bacterial suspension of Salmonella Typhimurium, and left during 0, 24, 48 and 72 hours at $+4 \pm 0.5^{\circ} \mathrm{C}$ and $+10 \pm 1^{\circ} \mathrm{C}$. Parts of the skin $(5 \times 4 \mathrm{~cm}$, from the flank), and previously tested and negative on Salmonella, were contaminated with bacterial suspension of Salmonella Typhimurium, and left during 0, 24, 48 and 72 hours at $+4 \pm 0.5^{\circ} \mathrm{C}$ and $+10 \pm 1^{\circ} \mathrm{C}$.

Bacteriological Analysis: "in vitro" studies were done, by contamination/ inoculation of minced meat samples and skin samples, separate, with three strains A, B and C of Salmonella Typhimurium, in six replicates. The total number of Salmonella was determined from the serial dilution and $1 \mathrm{~mL}$ from each dilution was transferred in two Petri dishes and than poured with XLD agar, and incubated at $37^{\circ} \mathrm{C}$ for $24 \mathrm{~h}$. The populations of bacterial cells were expressed in log CFU g ${ }^{-1}$ (minced meat) and CFU $\mathrm{cm}^{-2}$ (skin). 
Statistical Analysis: Experiments were done in six replicates. Data were subjected to analysis using MS Office Excel 2003 and Statgraphics 5.0.

\section{RESULTS}

The bacterial suspension of Salmonella Typhimurium strains A, B and C was inoculated in previously prepared pork minced meat and skin samples, in order to determine the changes in the number of Salmonella Typhimurium under "in vitro“ conditions. The effect of temperature $\left(+4 \pm 0.5^{\circ} \mathrm{C}\right.$ and $\left.+10 \pm 1^{\circ} \mathrm{C}\right)$ and time $(0,24$, 48 and $72 \mathrm{~h}$ ) on the changes in the population of Salmonella were studied.

Count of Salmonella Typhimurium in minced meat, stored at $+4 \pm 0.5^{\circ} \mathrm{C}$

The average number of Salmonella Typhimurium strain A, B and C expressed in log CFU g ${ }^{-1}$ decreased after $72 \mathrm{~h}$ at $+4 \pm 0.5^{\circ} \mathrm{C}$ compared with the initial value $(0 \mathrm{~h})$ (Table 1). On the basis of standard deviation $\left(S_{d}\right)$ for the values before and after the effects of temperature/time, can be seen that the data for log CFU g ${ }^{-1}$ are homogeneous within each group. Since the coefficient of variation $\left(C_{v}\right)$ is below $33 \%$ there was no significant variation in the bacterial population within the group. On the basis of the results of the LSD-test can be concluded that there is a significant difference in the change in the population of strains $A, B$ and $C$ before and after the treatment (Table 1).

\section{Count of Salmonella Typhimurium in minced meat, stored at $+10 \pm 1^{\circ} \mathrm{C}$}

The average number of Salmonella Typhimurium strain A and B expressed in log CFU g-1 increased, while strain C practically remained unchanged, after $72 \mathrm{~h}$ at $+10 \pm 1^{\circ} \mathrm{C}$ compared with the initial value $(0 \mathrm{~h})$ (Table 1$)$. On the basis of the standard deviation $\left(S_{d}\right)$ for the values before and after the effects of temperature / time it can be seen that data for $\log _{\text {CFU g }}{ }^{-1}$ are homogeneous within each group. Since the coefficient of variation $\left(C_{v}\right)$ is below $33 \%$, there was not a significant variation in the bacterial population within the group. On the basis of the LSD-test it can be concluded that there was a significant difference in the change in the population of strains $A$ and $B$ before and after the treatment (Table 1). Analysis of variance showed that the average number of strain $C$ before and after the treatment was not statistically significant.

\section{Count of Salmonella Typhimurium on pork skin, stored at $+4 \pm 0.5^{\circ} \mathrm{C}$}

The average number of Salmonella Typhimurium strains $A$ and $B$ expressed in $\log$ CFU cm$~_{-2}$ decreased, while strain $C$ slightly decreased, after $72 \mathrm{~h}$ at $+4 \pm$ $0.5^{\circ} \mathrm{C}$ compare with the initial value $(0 \mathrm{~h})$ (Table 2$)$. On the basis of the standard deviation $\left(S_{d}\right)$ fo $r$ the values before and after the effects of temperature / time can be seen that the data for log CFU cm$~^{-2}$ are homogeneous within each group. Since the coefficient of variation $\left(C_{v}\right)$ is below $33 \%$, there was no significant variation in the population of bacteria within the group. On the basis of the results of the 
LSD-test, can be concluded that there was a significant difference in the change in the population of strain $A$ and $B$ before and after the treatment (Table 2). Analysis of variance showed that the average number of strain $C$, before and after the treatment, was not statistically significant.

Table 1. Count of Salmonella Typhimurium in minced meat, stored at $+4 \pm 0.5^{\circ} \mathrm{C}$ and +10 $\pm 1^{\circ} \mathrm{C}$

\begin{tabular}{|c|c|c|c|c|c|c|c|c|c|c|c|c|}
\hline \multirow[b]{2}{*}{ Time } & \multicolumn{6}{|c|}{ Temperature $+4 \pm 0.5^{\circ} \mathrm{C}$} & \multicolumn{6}{|c|}{ Temperature $+10 \pm 1^{\circ} \mathrm{C}$} \\
\hline & $\bar{x}$ & $S_{d}$ & $\mathrm{~S}_{\mathrm{e}}$ & $\mathrm{X}_{\max }$ & $X_{\min }$ & $\begin{array}{c}C_{v} \\
(\%)\end{array}$ & $\bar{x}$ & $S_{d}$ & $\mathrm{~S}_{\mathrm{e}}$ & $X_{\max }$ & $X_{\min }$ & $\begin{array}{l}\mathrm{C}_{\mathrm{v}} \\
(\%)\end{array}$ \\
\hline & \multicolumn{12}{|c|}{ Salmonella Typhimurium strain A } \\
\hline $\mathrm{Oh}$ & $4.13^{a}$ & 0.18 & 0.07 & 4.43 & 3.95 & 4.38 & $3.78^{\mathrm{x}}$ & 0.13 & 0.05 & 3.96 & 3.66 & 3.56 \\
\hline $24 \mathrm{~h}$ & $4.30^{x}$ & 0.18 & 0.07 & 4.58 & 4.04 & 4.20 & $3.69^{x}$ & 0.065 & 0.03 & 3.80 & 3.63 & 1.76 \\
\hline $48 \mathrm{~h}$ & 4.03 & 0.30 & 0.12 & 4.30 & 3.63 & 7.37 & $4.05^{x}$ & 0.46 & 0.19 & 4.76 & 3.34 & 11.31 \\
\hline \multirow[t]{2}{*}{$72 \mathrm{~h}$} & $3.70^{b, y}$ & 0.37 & 0.15 & 4.18 & 3.27 & 10.04 & $4.63^{y}$ & 0.40 & 0.16 & 5.20 & 4.25 & 8.75 \\
\hline & \multicolumn{12}{|c|}{ Salmonella Typhimurium strain B } \\
\hline $0 \mathrm{~h}$ & $4.29^{x}$ & 0.12 & 0.05 & 4.5 & 4.14 & 2.81 & $4.25^{\mathrm{a}}$ & 0.09 & 0.04 & 4.34 & 4.11 & 2.26 \\
\hline $24 \mathrm{~h}$ & $4.30^{x}$ & 0.32 & 0.13 & 4.76 & 3.91 & 7.46 & $4.08^{\mathrm{b}, \mathrm{x}}$ & 0.06 & 0.02 & 4.20 & 4.04 & 1.53 \\
\hline $48 \mathrm{~h}$ & $4.16^{x}$ & 0.33 & 0.13 & 4.62 & 3.63 & 7.88 & $4.42^{\mathrm{b}, \mathrm{y}}$ & 0.16 & 0.07 & 4.67 & 4.23 & 3.76 \\
\hline \multirow[t]{2}{*}{$72 \mathrm{~h}$} & $3.68^{y}$ & 0.27 & 0.11 & 3.97 & 3.34 & 7.45 & $4.33^{y}$ & 0.17 & 0.07 & 4.58 & 4.17 & 4.034 \\
\hline & \multicolumn{12}{|c|}{ Salmonella Typhimurium strain C } \\
\hline $\mathrm{Oh}$ & $4.14^{x}$ & 0.16 & 0.07 & 4.45 & 4.00 & 4.00 & 3.93 & 0.16 & 0.06 & 4.17 & 3.70 & 4.04 \\
\hline $24 \mathrm{~h}$ & $4.31^{x}$ & 0.21 & 0.09 & 4.65 & 4.04 & 4.91 & 3.81 & 0.07 & 0.03 & 3.91 & 3.70 & 1.83 \\
\hline $48 \mathrm{~h}$ & $4.19^{x}$ & 0.40 & 0.16 & 4.66 & 3.53 & 9.48 & 3.89 & 0.19 & 0.08 & 4.20 & 3.59 & 5.02 \\
\hline $72 \mathrm{~h}$ & $3.61^{y}$ & 0.24 & 0.10 & 4.06 & 3.32 & 6.80 & 3.88 & 0.25 & 0.10 & 4.29 & 3.61 & 6.36 \\
\hline
\end{tabular}

Legend: $\bar{X}$ - mean value (log CFU g $\left.{ }^{-1}, n=6\right) ; S_{d}$ - standard deviation; $S_{e}-$ Standard error;

$\mathrm{X}_{\max }-$ maximum; $\mathrm{X}_{\min }-$ minimum; $\mathrm{C}_{\mathrm{v}}$ - coefficient of variation;

$a, b=p<0.05 ; x, y=p<0.01$;

Count of Salmonella Typhimurium on pork skin, stored at $+10 \pm 1^{\circ} \mathrm{C}$

The average number of Salmonella Typhimurium strain A, B and $C$ expressed in $\log$ CFU cm$~_{-2}$ decreased after $72 \mathrm{~h}$ at $+10 \pm 1{ }^{\circ} \mathrm{C}$ compared with the initial value $(0$ h) (Table 2). On the basis of the standard deviation (Sd) for the values before and after the effects of temperature / time can be seen that the data for log CFU cm${ }^{-2}$ are homogeneous within each group. Since the coefficient of variation $\left(C_{v}\right)$ is below $33 \%$ there was no significant variation in the bacterial population within the group. On the basis of the results of the LSD-test can be concluded that there was a significant difference in the change in the population of strain $A, B$ and $C$ before and after the treatment (Table 2). 
Table 2. Count of Salmonella Typhimurium on pork skin, stored at $+4 \pm 0.5^{\circ} \mathrm{C}$ and $+10 \pm 1{ }^{\circ} \mathrm{C}$

\begin{tabular}{|c|c|c|c|c|c|c|c|c|c|c|c|c|}
\hline \multirow{2}{*}{ Time } & \multicolumn{6}{|c|}{ Temperature $+4 \pm 0.5^{\circ} \mathrm{C}$} & \multicolumn{6}{|c|}{ Temperature $+10 \pm 1{ }^{\circ} \mathrm{C}$} \\
\hline & $\bar{x}$ & $\mathrm{~S}_{\mathrm{d}}$ & $\mathrm{S}_{\mathrm{e}}$ & $X_{\max }$ & $\mathrm{X}_{\min }$ & $\mathrm{C}_{\mathrm{v}}(\%)$ & $\bar{x}$ & $\mathrm{~S}_{\mathrm{d}}$ & $\mathrm{S}_{\mathrm{e}}$ & $\mathrm{X}_{\max }$ & $X_{\min }$ & $\mathrm{C}_{\mathrm{v}}(\%)$ \\
\hline & \multicolumn{12}{|c|}{ Salmonella Typhimurium strain A } \\
\hline $\mathrm{Oh}$ & $4.32^{x}$ & 0.22 & 0.09 & 4.62 & 4.11 & 5.16 & $4.03^{a, x}$ & 0.19 & 0.07 & 4.25 & 3.81 & 4.80 \\
\hline $24 \mathrm{~h}$ & $3.98^{a}$ & 0.37 & 0.15 & 4.36 & 3.50 & 9.36 & $3.44^{y}$ & 0.12 & 0.05 & 3.60 & 3.32 & 3.57 \\
\hline $48 \mathrm{~h}$ & $4.15^{\mathrm{a}}$ & 0.11 & 0.04 & 4.30 & 4.00 & 2.61 & $3.71^{\mathrm{b}}$ & 0.16 & 0.06 & 4.01 & 3.60 & 4.34 \\
\hline \multirow[t]{2}{*}{$72 \mathrm{~h}$} & $3.57^{\mathrm{b}, \mathrm{y}}$ & 0.41 & 0.17 & 4.11 & 3.26 & 11.60 & $3.60^{y}$ & 0.38 & 0.16 & 4.20 & 3.13 & 10.62 \\
\hline & \multicolumn{12}{|c|}{ Salmonella Typhimurium strain B } \\
\hline $\mathrm{Oh}$ & $4.18^{\mathrm{a}, \mathrm{x}}$ & 0.15 & 0.06 & 4.41 & 4.06 & 3.54 & $3.91^{\mathrm{a}, \mathrm{x}}$ & 0.14 & 0.05 & 4.10 & 3.70 & 3.49 \\
\hline $24 \mathrm{~h}$ & $4.20^{\mathrm{a}, \mathrm{x}}$ & 0.14 & 0.06 & 4.32 & 3.96 & 3.32 & $3.58^{\mathrm{b}, \mathrm{c}}$ & 0.06 & 0.02 & 3.65 & 3.48 & 1.58 \\
\hline $48 \mathrm{~h}$ & $75^{b}$ & 0.51 & 0.21 & 4.14 & 3.08 & 13.72 & $3.47^{c, y}$ & 0.32 & 0.13 & 3.78 & 3.00 & 9.14 \\
\hline \multirow[t]{2}{*}{$72 \mathrm{~h}$} & $3.29^{y}$ & 0.16 & 0.07 & 3.49 & 3.04 & 4.95 & $3.78^{a, b}$ & 0.34 & 0.14 & 4.30 & 3.41 & 9.05 \\
\hline & \multicolumn{12}{|c|}{ Salmonella Typhimurium strain C } \\
\hline $0 \mathrm{~h}$ & 3.89 & 0.30 & 0.12 & 4.24 & 3.48 & 7.78 & $3.94^{x}$ & 0.18 & 0.07 & 4.23 & 3.71 & 4.55 \\
\hline $24 \mathrm{~h}$ & 3.89 & 0.34 & 0.14 & 4.24 & 3.30 & 8.76 & $3.62^{y}$ & 0.04 & 0.02 & 3.66 & 3.54 & 1.13 \\
\hline $48 \mathrm{~h}$ & 4.01 & 0.39 & 0.16 & 4.36 & 3.24 & 9.86 & $3.45^{y}$ & 0.20 & 0.08 & 3.73 & 3.17 & 5.88 \\
\hline $72 \mathrm{~h}$ & 3.57 & 0.30 & 0.12 & 4.05 & 3.27 & 8.29 & $3.57^{y}$ & 0.28 & 0.12 & 3.93 & 3.19 & 7.98 \\
\hline
\end{tabular}

Legend: $\bar{x}$ - mean value ( $\log C F U \mathrm{~cm}^{-2}, \mathrm{n}=6$ ); $\mathrm{S}_{\mathrm{d}}$ - standard deviation; $\mathrm{S}_{\mathrm{e}}$ - Standard error; $\mathrm{X}_{\max }-$ maximum; $\mathrm{X}_{\min }-$ minimum; $\mathrm{C}_{\mathrm{v}}$ - coefficient of variation;

$a, b, c=p<0.05 ; x, y=p<0.01$;

\section{DISCUSSION}

Animals, feed, meat and its products are often transported long distances and represent a significant part of international trade, which enables the dissemination of Salmonella, including drug-resistant strains. Pigs are an important reservoir of Salmonella, which is "inside" the gastrointestinal tract and associated lymphoid tissue. On the other hand, in the last decade, it has been told much about the hypothesis that the food and feed chain are "too clean". It was one of the reasons for some foodborne poisoning caused by bacteria (Dickinson and Olson, 2001; Jay, 1995). If this hypothesis is true, in future, we will face the problems related to subsequent contamination, and in the absence of competitive flora pathogens may be favored. In general, the safest way to control the growth of Salmonella is to maintain the cold chain and high temperatures. However, certain strains, like Salmonella Senftenberg are relatively resistant to heat. If the storage temperature is not below $7^{\circ} \mathrm{C}$, Salmonella can multiply in the food. Also, it shouldn't be ignored that Salmonella is able to survive longer periods in foods where its multiplication for some reason is not possible. 
According to the reported data, the most common Salmonella finding in pork is Salmonella Typhimurium (Delhalle et al., 2009; Jordan et al., 2006). Hence two strains of Salmonella Typhimurium (strain A and B) from a slaughterhouse source were chosen for the "in vitro" study. Besides these two strains, a third strain, from a clinical/human source, of Salmonella Typhimurium (strain C) was used, also. Samples of minced meat and pork skin, were checked on Salmonella presence and the results were negative. Contaminated samples, have been stored, in adequate cooling conditions at $+4^{\circ} \mathrm{C}$ and in inadequate cooling conditions at $+10^{\circ} \mathrm{C}$ during $0 \mathrm{~h}, 24 \mathrm{~h}, 48 \mathrm{~h}$, and $72 \mathrm{~h}$. According to the Regulations on the quality and other requirements for meat products (Official Gazette RS No 31/12), the prescribed temperature of minced meat at the moment of prepartion and sale is $0-7^{\circ} \mathrm{C}$ and if prepacked is $0-2^{\circ} \mathrm{C}$. It's not rare that in the retail network, prepared minced meat is kept in inadequate cooling conditions which often exceed $+7^{\circ} \mathrm{C}$, i.e. the critical temperature for growth of Salmonella. As well, consumers lifestyle has changed and once a week shopping is more common, leading to refrigation of minced meat for hours or days before consumption (Koutsoumanis et al., 2008). We wanted to determine whether there was a significant change in the number of these bacteria in pork minced meat under "in vitro" conditions, and if there is a difference between the strains isolated in the slaughterhouse and the clinical / human strain.

The finding of Salmonella in minced meat ranges from 3.2 to $57.1 \%$ on the basis of 3237 samples examined in Mexico, Netherlands and the USA (D'Aoust, 2000). According to data (Moller et al., 2013) when comparing growth curves of Salmonella obtained in sterile ground pork to curves obtained in pork with a natural microbiota at identical temperatures, they found that high concentrations of the natural microbiota reduce growth of Salmonella. The nature of the interaction was that growth of Salmonella in ground pork with a natural microbiota was identical to growth in sterile pork until high levels of the natural microbiota were reached. At that point, Salmonella growth slowed down considerably. We did not examine the interaction between natural microflora of minced meat and Salmonella. In the minced meat stored at $+4 \pm 0.5^{\circ} \mathrm{C}$ for $72 \mathrm{~h}$, the number of all three investigated Salmonella Typhimurium strains A, B, C decreased, and a statistically significant difference $(p<0.01)$ between the initial number and the number of salmonella after $72 \mathrm{~h}$ of storage was determined. After $24 \mathrm{~h}$ of cooling there was no significant decrease in the number of strains $A, B, C$, nor after $48 \mathrm{~h}$ compared with the initial value of the number of salmonella strains. Under inadequate cooling conditions at $+10 \pm 1^{\circ} \mathrm{C}$, after $72 \mathrm{~h}$, the number of Salmonella strain A was significantly higher than the initial number $(p<0.01)$. The difference between the initial number of salmonella strains $B$ and $C$ and the number of salmonella strains in minced meat after $72 \mathrm{~h}$ of storage was not statistically significant $(p>0.05)$.

Previously published papers (Karabasil et al., 2012a; Karabasil et al., $2012 b$ ) was largely based on the pathways of contamination of pork carcasses in slaughterhouses. As already mentioned, the sources and pathways of 
contamination of pork carcasses by Salmonella are numerous (Kranken et al., 2003; Rostagno et al., 2003; Hurd et al., 2002). Therefore, it seemed interesting to see what happened with Salmonella on pork skin during refrigeration, whether the population decreased, stagnated or its number increased. The same refrigeration temperatures were applied for the the skin samples as for minced meat. Unlike minced meat, which contains fat, and can protect Salmonella from low temperatures, skin samples do not have such capabilities and its surface dries quickly, which is not favorable for Salmonella.

On the pork skin, after storing at $+4 \pm 0.5^{\circ} \mathrm{C}$ during $72 \mathrm{~h}$, the number of Salmonella strains $A$ and $B$ decreased, so there was a statistically significant difference between the initial number and the number of these Salmonella strains after $72 \mathrm{~h}$ of storage $(p<0.01)$. Between the initial number of Salmonella strain $\mathrm{C}$ and the number of the same Salmonella strain on the skin after $72 \mathrm{~h}$ of storage there was no statistically significant difference $(p>0.05)$. Numerically speaking, the number of Salmonella strains $\mathrm{C}$, decreased compared to the initial value, but with no statistical significance after $72 \mathrm{~h}$ of storage. In inadequate storage conditions at $+10 \pm 1^{\circ} \mathrm{C}$ during $72 \mathrm{~h}$, the number of Salmonella strains $A$ and $C$ decreased, so that between the initial number and the number of these salmonella strains after $72 \mathrm{~h}$ of storage statistically significant difference $(p<0.01)$ was determined. Between the initial number of Salmonella strain $\mathrm{B}$ and the number of the same Salmonella strain on the skin after $72 \mathrm{~h}$ of storage there was no statistically significant difference $(p>0.05)$. The number of Salmonella strain C after $24 \mathrm{~h}(p<0.05)$ and $48 \mathrm{~h}(p<0.01)$ of storage was significantly decreased compared to the initial value. After 48 hours of storage of Salmonella strain B, the number of bacteria started to increase and after $24 \mathrm{~h}$ ( $72 \mathrm{~h}$ of storage), the number of bacteria was significantly higher $(p<0.05)$.

Salmonella, is often associated with outbreaks related to meat consumption and foodborne diseases worldwide (Rhoades JR et al., 2009). Poor hygiene practice and improper food handling, might result in cross-contamination in meat processing plants (Perez-Rodriquez et al., 2010) and in private kitchens too, even more frequently (Redmond and Griffith, 2003). Published results have showed that the tested equipment might contaminate food products during handling at various inoculum levels (Papadopoulou et al., 2012.). Therefore, our results indicate the importance of using good hygiene and manufacturing practices in slaughterhouses and in households, as well.

Address for correspondence:

Neđeljko Karabasil,

Department of Food Hygiene and Technology of Animal Origin

University of Belgrade,

Faculty of Veterinary medicine

Bulevar oslobođenja 18

11000 Belgrade, Serbia,

E-mail: nedja@vet.bg.ac.rs 


\section{REFERENCES}

1. D'Aoust JY, 2000, Salmonella; Chapter 45 in „The Microbiological safety and quality of food“. (Lund BM, Baird-Parker AC, Gould GW., eds), Vol II, 1233-99.

2. Delhalle L, Saegerman C, Farnir F, Korsak N, Maes D, Messen W et al., 2009. Salmonella surveillance and control at post-harvest in the Belgian pork meat chain, Food Microbiol, 26, 3, 265-71.

3. Dickson JS, OIson DG, 2001, Growth rates on Salmonella and Escherichia coli O157:H7 in Irradiated Beef, J Food Protection, 64, 11, 1828-31.

4. Institute of Public Health of Serbia and WHO. 2010. Top 15 lists from a Country, (http://thor. dfvf.dk/pls/portal/GSS.COUNTRY_DATA_SET_REP.show_parms).

5. Hurd HS, McKean JD, Griffith RW, Wesley IV, Rostagno MH, 2002. Salmonella enterica infections in market swine with and without transport and holding, Appl Environment Microbiol, 68, 2376-81.

6. Janković Ljiljana, Radenković Damjanović Brana, Karabasil N., Mirilović M., Marić S. 2012. Ispitivanje uticaja postupaka dezinfekcije na higijenu u zanatskoj klanici, Vet glasnik, 66, 3-4, 219-31.

7. Jay $J M, 1995$. Food with low numbers of microorganisms may not be the safest foods. Or why did human listeriosis and Hemorrhagic colitis become foodborne diseases? Dairy Food Environ Sanit, 15, 674-77.

8. Jordan E, Egan J, Dullea C, Ward J, McGillicuddy K, Murry G et al., 2006. Salmonella surveillance in raw and cooked meat products in the Republic of Ireland from 2002 to 2004, Int J Food Microbiol, 112, 66-70.

9. Karabasil N, Dimitrijević M, Kilibarda N, Galić N, Petrović J, 2012c. Salmonella serotype prevalence in two pig slaughterhouses. Proceedings of the International Conference: Biological Food safety \& Quality, BFSQ 2012, Belgrade, Serbia, 4-5 October 2012, 64-7.

10. Karabasil N, Dimitrijević M, Kilibarda N, Teodorović V, Baltić ŽM, 2008, Značaj salmonela u proizvodnji mesa svinja, Vet glasnik, 62, 5-6, 259-75.

11. Karabasil N, Dimitrijević M, Pavličević N, Teodorović V, Lončina J, Nedeljković Trailović J et al., 2012a. Nalaz salmonela na površinama u stočnom depou i boksu za omamljivanje svinja, Vet glasnik, 66, 3-4, 233-42.

12. Karabasil N, Pavlićević N, Galić N, Dimitrijević M, Lončina J, Ivanović J et al., 2012b, Nalaz salmonela na trupovima svinja u toku klanja i obrade, Vet glasnik, 66, 5-6, 377-86.

13. Koutsoumanis KP, Stamatiou AP, Drosinos EH, Nychas GJE. 2008. Control of spoilage microorganisms in minced pork by a self-developed modified atmosphere induced by the respiratory activity of meat microflora, Food Microbiol, 25, 915-25.

14. Kranken S, Alban L, Boes J, Dahl J, 2003, Longitudinal Study of Salmonella enterica Serotype Typhimurium Infection in Three Danish Farrow-to-Finish Swine Herds, J Clin Microbiology, 41, 6, 2282-8.

15. Moller COA, Ilg Y, Aabo S, Christensen BB, Dalgaard P, Hansen TB, 2013, Effect of natural microbiota on growth of Salmonella spp. in fresh pork - a predictive microbiology approach, Food Microbiol, 34, 284 - 95.

16. Official Gazette RS No 31/12. 2012. Pravilnik o kvalitetu ustinjenog mesa, poluproizvoda od mesa i proizvoda od mesa, Službeni glasnik Republike Srbije, broj 31/12.

17. Papadopoulou OS, Chorianopoulos NG, Gkana EN, Grounta AV, Koutsomanis KP, Nychas GJE, 2012. Transfer of foodborne pathogenic bacteria to non - inoculated beef fillets through meat mincing machine, Meat Sci, 90, 865-9.

18. Perez-Rodriquez F, Castro R, Posada Izquierdo GD, Valero A, Carrasco E, Garcia Gimeno $R M$, Zurera $G, 2010$, Evaluation of hygiene practices and microbiological quality of cooked meat products during slicing and handling at retail, Meat Sci, 86, 479-85.

19. Prendergast DM, Duggan SJ, Gonzales-Barron U, Fanning S, Butler F, Cormican M, et al., 2009, Prevalence, numbers and characteristics of Salmonella spp. on Irish retail pork, Int J Food Microbiol, 131, 2-3, 233-9. 
20. Redmond EC, Griffith CJ, 2003, Consumer food handling in the home: A review of food safety studies, J Food Prot, 66, 130-61.

21. Rhoades JR, Duffy G, Koutsoumanis K, 2009. Prevalence and concentration of verocytotoxigenic escherichia coli, Salmonella enterica and Listeria monocytogenes in the beef production chain: A review, Food microbiol, 26, 357-76.

22. Rostagno MH, Hurd HS, McKean JD, Ziemer CJ, Gailey JK, Leite RC, 2003, Preslaughter holding environment in pork plants Is highly contaminated with Salmonella enterica, Appl Environm Microb, 4489-94.

23. Small A, Reid CA, Avery SM, Karabasil N, Crowley C, Buncic S, 2002. Potential for the spread of Escherichia coli O 157, Salmonella and Campylobacter in the lairage environments at abattoirs, J Food Prot, 65, 931-6.

24. Smerdon WJ, Adak GK, O`Brien SJ, Gillespie IA, Reacher M, 2001. General outbreaks of infectious intestinal disease linked with red meat, England and Wales, 1992-1999, Commun Dis Public Health, 4, 259-67.

\section{PREŽIVLJAVANJE SALMONELLA TYPHIMURIUM U USITNJENOM MESU I KOŽı SVINJA PRI RAZLIČITIM TEMPERATURAMA}

KARABASIL N, TEODOROVIĆ V, DIMITRIJEVIĆ MIRJANA, PAVLIĆEVIĆ NATAŠA, KURELJUŠIĆ JASNA, SOČO I. ĐURIĆ SPOMENKA I SAVIĆ RADOVANOVIĆ RADOSLAVA

\section{SADRŽAJ}

Salmonele predstavljaju važnije patogene, a meso svinja jedan je od glavnih izvora infekcije potrošača. Samim tim, za efektivnu kontrolu ovog patogena svaka karika u lancu hrane ima svoj značaj. Cilj ovog rada je bio da se ispita promena broja Salmonella Typhimurium, sojeva poreklom iz klanice i kliničkog/ humanog materijala, u mlevenom mesu i koži svinja pri različitim temperaturama hlađenja i vremenu skladištenja, radi boljeg poznavanja pojedinih kritičnih mesta u lancu hrane. U mlevenom mesu, skladištenom pri $+4 \pm 0.5^{\circ} \mathrm{C} u$ toku $72 \mathrm{~h}$, broj salmonela sva tri ispitivana soja (Salmonella Typhimurium soj $\mathrm{A}, \mathrm{B}$, $\mathrm{C})$ je opadao $(p<0.01)$. U mlevenom mesu skladištenom pri $+10 \pm 1^{\circ} \mathrm{C}$ posle $72 \mathrm{~h}$ broj salmonela soja $A$ je značajno veći u odnosu na inicijalni broj $(p<0.01)$, dok kod sojeva B i C nije utvrđena statistički značajna razlika ( $p>0.05)$. Na koži svinja, skladištenoj pri $+4 \pm 0.5^{\circ} \mathrm{C}$ u toku $72 \mathrm{~h}$, broj salmonela soja $A$ odnosno $B$ je opadao $(p<0.01)$, dok kod soja $C$ nije utvrđena statistički značajna razlika ( $p>0.05$ ). Na koži svinja, skladištenoj pri $+10 \pm 1^{\circ} \mathrm{C}$ u toku $72 \mathrm{~h}$, broj salmonela soja A odnosno $C$ je opadao $(p<0.01)$, dok kod soja $B$, nije utvrđena statistički značajna razlika $(p>0.05)$. 